\title{
Hypocrisy in The Man in Black: A Critical Analysis
}

\author{
Mary Raymer \\ Assistant Professor, St. Aloysius' College, Jabalpur, Madhya Pradesh, India
}

\section{OPEN ACCESS}

Manuscript ID:

ENG-2021-09033872

Volume: 9

Issue: 3

Month: June

Year: 2021

P-ISSN: 2320-2645

E-ISSN: 2582-3531

Received: 29.03.2021

Accepted: 05.05.2021

Published: 01.06.2021

Citation:

Raymer, Mary, and Neha

Mahawar. "Hypocrisy

in The Man in Black: A

Critical Analysis." Shanlax

International Journal of

English, vol. 9, no. 3, 2021,

pp. 28-33.

DOI:

https://doi.org/10.34293/

english.v9i3.3872

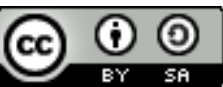

This work is licensed under a Creative Commons Attribution-ShareAlike 4.0 International License

\section{Neha Mahawar}

St. Aloysius' College, Jabalpur, Madhya Pradesh, India

\begin{abstract}
Oliver Goldsmith's The Man in Black is a brilliant literary illustration of an unspoken social evilhypocrisy. There is nothing without a reason, thus, hypocrisy was dissected to reveal the inner truth and various practical ways were found to get some more essence of humanity back to its true owners, humans. The depth of hypocrisy within the society and how it manages to continue to prevail was also discussed in detail with a strong affirmation of the essay, hypocrisy and Albert Bandura's "Social Learning Theory". It is intriguing how a literary text lies in complete understanding of a theory put up more than a century later.

The research paper has a psychological, philosophical and literary attributes orchestrated to highlight the social reformations needed in the world. With the world getting smaller, our souls need to get bigger to live a life worth living.

Keywords: Hypocrisy, Self awareness, Character, Society, Oliver Goldsmith, The Man in Black, Albert Bandura, Social learning theory, Hypocrisy, Reasons for hypocrisy, Psychoanalysis of a hypocrite, Ways to cope with hypocrisy, Society, Empathy, Sympathy
\end{abstract}

"Write as it matters, and it will." - Libba Bray

\section{Statement}

The purpose of the paper is to probe the causes of hypocrisy, to understand the depth of its association with Albert Bandra's "Social Learning Theory" as hypocrisy was well established in the essay of Oliver Goldsmith The Man in Black. The paper further investigates the possible remedies to smoothen the concept of hypocrisy.

Oliver Goldsmith essay Man in Black is written in complete coherence with the aforesaid quote. Oliver Goldsmith did not write the essay for the mere fact of writing. He wrote it because what he spoke about in the essay mattered to him, and to his principles of living a good life. Oliver Goldsmith an Irish novelist, playwright and, poet, the one who rose from a humble beginning to strive and see the glory his name almost even two-hundred and fifty years after his death. When one reads about the life of Goldsmith, nothing is noteworthy if read breezily. But if one observes his mannerisms and lifestyle closely. It has an affinity between the character, Man in Black, and Goldsmith himself.

Goldsmith supposedly an unorganized man, not having ample financial aid to lead a settled life. No matter how much he earned, was found giving away his earnings for a noble cause that he encountered. Washington Irving asserts, “... The money that he sporadically earned was often frittered away or happily given away to the next good cause that presented itself so that any financial security tended to be fleeting and short-lived". Several critics share a similar view of the personalities of the Man in Black and Goldsmith. 
It was noticed Goldsmith himself seemed to have difficulty reconciling his philosophic opposition to charity with his tenderness toward the poor - the conservative, with the man of feeling.... As foolishly "luxurious" as Goldsmith may have considered [the Man in Black's] behaviour, he found it natural and almost unavoidable for a "man of sentiment".

The resemblance between the character the Man in Black and Goldsmith is the fact that both tried to do their best to help someone in need, at times putting themselves out of resources. Goldsmith never shied away from helping someone, be it personally or publicly however, his character did not exhibit the same trait. There is an element that is unique to the Man in Black. He preached from the very beginning of the essay till the very end, how one must not help beggars as "... they are imposters,..."

The essay is narrated by an anonymous person who sings all glory of the goodness of his friend, the Man in Black. He mentions how his friend makes immense efforts to showcase himself as someone is not as he says, "He takes as much pains to hide his feelings, as any hypocrite would to conceal his indifference...", In the above mentioned line, irrespective of being eloquently orchestrated, brings out the aspect which will be dealt in detail in this paper, hypocrisy. Some people also term it as "Moral Hypocrisy". The Cambridge Dictionary defines hypocrisy as "a situation in which someone pretends to believe something that they do not believe, or that is opposite of what they do or say at another time." Another definition provided by the same is, "pretending to be what you are not, or pretending to believe something that you do not". According to Oxford Learner's Dictionaries it defines hypocrisy as "behavior in which someone pretends to have moral standards or opinions that they do not have". Going by the literal definitions, it clearly states the character of Man in Black was a hypocrite.

His friend, the narrator of the essay, also brings out the different personalities he observes in his friend. He mentions, "I have known him profess himself a man-hater, while his cheek was glowing with compassion." The entire essay perhaps is more of a written proof of the Man in Black's hypocrisy. Throughout the length of the essay, the Man in Black vocally advocates against those who help the poor. He says, "... let me assure you, sir, they are imposters, every one of them; and rather merit a prison than relief." He was expressing his surprise that there were people who were helping the poor. As for him, the only thing that the poor deserved to get was a cell in a prison. However, when he encountered three different people who had to take up begging to survive, to try and get one square meal for themselves and their families, the Man in Black helped each one of them. The first beggar was given a piece of silver, to the second he gave a shilling and bought the entire cargo from him. When he encountered the third beggar, he realized he was running short of money. He was agonized when he didn't find any money to help the poor woman. All he had was the bundles of chips that he had bought from the second beggar. Without a second thought, he gave away all of it to the poor woman.

This reveals that he was ready to run out of his resources reach out to the needy and help them in any possible manner he could think of. However, he is the same person who was advising his friend, hardly a little while ago, to imprison all the beggars. He articulates, "Were I to advise any man for whom I had the least regard, I would caution him by all means not to be imposed upon by their false pretence..." This accomplishes the fact that one of the striking features of the character of the Man in Black was his hypocrisy. He preached one thing and when given a chance, he would do the opposite. Therefore, the Man in Black was a hypocrite undoubtedly.

If the Man in Black was a real person, there had to be some reasons as to why he was the way he was. There had been many moral philosophers and psychologists who have tried their hands at the psychoanalysis of a hypocrite. Yet, not much can be said about it. The most likely reasons for hypocrisy could be:

Self-Unawareness: this reason in unison with the reasoning given by Carl Jung. "The mere fact that humans are not as aware of their personalities as they should be is a prime reason for him/her to turn into a hypocrite"When the person does not acknowledge the characteristics of himself, he does not get accustomed to the practices and beliefs he does believe in, intentionally or unintentionally, he will tend to portray to the others as if he believes in 
something else, even though deep within, he'd hold back strongly his beliefs.

Self-Ignorance: this reason corresponds Robert Wright's reasoning. He proposes that, "Humans are more precise and accurate when judging others whereas they tend to be biased or loosen up a little when judging themselves" Thus, even though a person knows his/ her beliefs, it is equally imperative to put themselves superior to anyone else.

Self-Interest: A person could act like a hypocrite when that could turn the following events in his favour. Humans tend to let go off certain restrictions when they are in a position where a tad bit of compensation of their beliefs could turn the tables in favour of them.

Self-Unacceptance: Even when a person knowledge of his/her likes and dislikes and understands what principles he/she would live his/ her life on, there is yet a need of acceptance. Until a person accepts things the way they are, pretense will continue. A person has to acknowledge and accept the moral codes he/she believes in for a proper understanding of the self and his/her behavior.

Self-Deception: Benjamin Franklin was the one who had come up with this reasoning. "A person who is aware of his principles and still denies his belief in them. It is different to be aware of his beliefs and not accept them and denying them."

Public Image: A person could put on a disguise be in the good books of the public. It is easier to make things seem a particular way than working to make them be that way. The same way, when people need public validations and for various reasons, want to be in the good books of the majority, they somehow bring themselves to compensate their beliefs as a disguise, irrespective of the fact that away from the shadows of the crowd, he is doing the exact thing he believed in but publicly denied tobe a follower of.These reasons spoke of the how a person and his psychology can determine whether he or she takes up hypocrisy or not. There is another reason which is not individual centric yet holds an equal importance in moulding a man to a hypocrite.

Society: The last but not the least, usually unspoken, reason is the society. This reason is backed by the theory put forward by Albert Bandura called the "Social Learning Theory".
As per this theory, Bandura with a series of experiments proved that "all learning was a result of direct experience with the environment through the processes of association and reinforcement.". Similarly, when children observe hypocrisy in all forms all around them, they accept it as a part of humankind without questioning it. The society is made up of the individuals. We have already discussed why an individual could act like a hypocrite. When such individuals come together, they put forth a society that we see today.

Hypocrisy has become such an inbuilt part of our daily conversations that it has become difficult to identify the tinge of hypocrisy in our colloquial language. Hypocrisy is not a bad quality. It is the intensity to which it is take up to that has turned it into a negative characteristic. Hypocrisy is needed in the society but it cannot overpower the basic human features. Hypocrisy is not a bad attribute. It is the intensity to which it is taken up to that has turned it into a negative characteristic.

Hypocrisy is needed in the society but it cannot overpower the basic human features. It should be opted for in order to reduce the damage caused to others rather than to gain some profit.

Imagine a rose plant with some beautiful roses grown on it. There are red roses, pink ones and even some yellow roses. The plant is healthy and the leaves show signs of good nurturing.

In all, we see the brown soil, green stem, thorns and leaves, red, pink and yellow roses.

Now imagine another rose plant which was kept right beside the first one. It has roses which are grown out of proportionality. They make the entire plant look hideous. There is no sight of the soil or the leaves, all one can see is are huge flowers. If asked to pick one for yourself, which one would you choose? The answer would be the first plant.

The plant is a metaphor for humankind and the flower for hypocrisy. When the flower is within proportion to the plant, it adds to its beauty. It acts as a deviation from the sight of the thorns for the viewers which might not be so pleasant to them and yet, the other aspects of the plant are also evident to the viewer. However, if the flower grows out of proportion and it covers everything else the plant contains, it is only superficial and the only thing 
with which the plant would be associated would be the flowers. Similarly, if hypocrisy is all that a man displays then it would be the only thing we'd associate with that man. Hypocrisy, if used judiciously, can make a person's personality better but such can only be the case when other attributes of that person are significantly displayed as well and that hypocrisy does not over power any one of them.

Some philosophers and psychologists have written down some remedial acts to reduce the effects of over use of hypocrisy:

Self-Awareness: Carl Jung had written in his works, "It is under all circumstances an advantage to be in full possession of one's personality, otherwise the repressed elements will only crop up as a hindrance elsewhere, not just at some unimportant point, but at the very spot where we are most sensitive.... A little less hypocrisy and a little more self-knowledge can only have good results in respect for our neighbor..." Very simply, Jung has laid down the importance of self- awareness. Self- awareness acts as a mirror to one's self and also gives a clarity of thought on how to behave socially. It brings a self of belongingness, a sense of connectivity between the soul, the mind and the body as each of the three are well aware of the strengths and the shortcomings of the individual. Meditation, introspection, emotion journaling, loud thinking, writing are some ways a person can try to explore themselves and understand themselves and their ways.

Self-Acceptance: Robert Wright wrote,"Human beings are a species splendid in their array of moral equipment, tragic in their propensity to misuse it, and pathetic in their constitutional ignorance of the misuse." Humans should introspect, spend time with themselves in order to realize what beliefs form the backbone of their ways of living. They shouldn't stop at just realizing, they need to accept themselves the way they are even if certain realizations are not as per the expectations they have from themselves. Changes can always be inculcated but first there is a need to accept that change is needed.

Self-Validation: An observation made by Benjamin Franklin says, "So convenient a thing is it to be a reasonable creature, since it enables one to find or make a reason for everything one has a mind to do." Human beings are complex but humanity is not. Before acting humbly with another individual, it is imperative that one behaves humbly with himself.

How the world perceives an individual is completely subjective and is open to alternations every now and then. Every individual needs to understand that it is not necessary to look for acceptance from others in order to validate his/ her actions/ thoughts/ feelings. The only person who can undoubtedly apprehend the ways of living of a person without any mistake is that person himself.

Thus, humans should stop relying on others' approval of their behavior because nobody can completely understand the reasons behind it and there will never be a time when each and every individual agrees to their behavior. Someone or the other will come up with a different opinion. So, it is important to validate one's actions themselves.

Empathy: Carl Jung had also mentioned, "If people can be educated to see the shadow-side of their nature clearly, it may be hoped that they will also learn to understand and love their fellow men better." He also opined, "... we are all too prone to transfer to our fellows the injustice and violence we inflict upon our own nature".

Consider the following scenarios:

- You got to work one Monday. It is a fresh start of the week and you're quite rejuvenated for the upcoming week. Unfortunately, you trip a couple of flight of stairs and hurt your ankle. You go to a doctor and you get a plaster. The next day at work, you're barely able to move around. You're walking with the help of the help of underarm crutches. You manage to reach your seat. Your colleagues enquire of your condition. Some of them offer their help to you, they are sympathizing with you. However, they don't really understand your pain.

- It has been a couple of that incident. The plaster is long gone. You reach work and you see a fellow worker in a similar condition as you're a couple of months ago. She has injured her foot and has got a plaster. This time, when all her colleagues (including you) enquire of her condition, everyone else will offer their help out of sympathy. However, you would be able to feel every bit of her pain and her struggle so you'd probably give her some tips to cope better 
with the situation. Later, you see her walking to the elevator and you recall the times when you were struggling your way to the elevator. You instantly stand up and help her. The reason is that you know how difficult and painful it was for you to walk all the way because you had experienced it yourself.

- These scenarios help us realize that humans can connect with others more efficiently when they have a sense of belongingness. In the above stated example, you could connect with your colleague because both of you belonged to the same category of pain.

- The sense of empathy helps us create that sense of belongingness, sense of connectivity.

- When an individual empathizes with another, he is able to understand the conditions of the other instead of just pitying them. Thus, empathy tends to connect all individuals as one which makes the world a better place to live in because no person turns a blind eye towards the other's situation. Rather, when there is a level of understanding, there is hope of better behavior.

The essay therefore is a perfect example of the various remedies which can be employed in order to sustain with humility and least hypocrisy when the Man in Black helped the ones in need by letting go off his hypocritical mask as he was self- aware and had accepted his beliefs. He has also shown great signs of empathy at all times whenever he had encountered a person in need.

\section{Conclusion}

Oliver Goldsmith's essay "The Man in Black" is found to be in complete coherence with Albert Bandura's "Social Learning Theory" which was initially outlined in 1963 and further detailed in 1977.Further it can be deduced that even though the theory was given in 1977 but the characteristics had been prominent, in almost alike manners, even a century ago. With various reasons suggested by wellknown psychologists and found during the research have been mentioned in detail along with certain suggested measures for them. This research is also a social appeal to mankind to get more empathetic to become 'man' who is 'kind', not only to fellow humans but to every aspect of nature.

\section{References}

“Albert Bandura." Wikipedia, https://en.wikipedia. org/wiki/Albert_Bandura

Cherry, Kendra. "What the Bobo Doll Experiment Reveals about Kids and Aggression." Very Well Mind, 2020.

Craik, Henry. "The Man in Black." English Prose: Selections with Critical Introductions by Various Writers and General

Crossman, Ashley. "Major Sociological Theories: A List of Sociological Theories, Concepts and Frameworks." ThoughtCo, 2019.

Culatta, Richard. "Social Learning Theory (Albert Bandura)." Instructional Design, https:// www.instructionaldesign.org/theories/sociallearning

Gobet, Fernand, and Omar Yousaf. "Hypocrisy Paradigm." The SAGE Encyclopedia of Political Behavior. Edited by Fathali M. Moghaddam, Sage Publications, 2017.

Hirschfeld, Lawrence A. "The Child's Representation of Human Groups." Psychology of Learning and Motivation, vol. 31, 1994, pp. 133-185.

https://courses.lumenlearning.com/sociology/ chapter/theoretical-perspectives-on-society

Hunt, Alan J. Satire Oliver Goldsmith's The Citizen of the World. Ball State University, 1979.

Hunter, Dianne M. "The Man in Black." PSYART: A Online Journal for the Psychological Study of the Arts, 2004.

"Hypocrisy." Cambridge Dictionary, https:// dictionary.cambridge.org/dictionary/english/ hypocrisy

"Hypocrisy." Merriam-Webster, https://www. merriam-webster.com/dictionary/hypocrisy

"Hypocrisy." Oxford's Learner's Dictionaries, https://www.oxfordlearnersdictionaries.com/ definition/english/hypocrisy

"Hypocrisy." Wikipedia, https://en.wikipedia.org/ wiki/Hypocrisy

Introductions to Each Period - Vol 4. The Macmillan Company, 1916.

Kurt, Serhat. "Social Learning Theory: Albert Bandura." Educational Technology, 2020.

Leiter, Brian. "Nietzsche's Moral and Political Philosophy." The Stanford Encyclopedia of Philosophy, 2020. 
McLeod, Saul. "Albert Bandura's Social Learning Theory." Simple Psychology, 2016.

Misirlisory, Erman. "The Science of Hypocrisy." Medium, 2018.

"Moral Hypocrisy." Psychology, http://psychology. iresearchnet.com/social-psychology/ antisocial-behavior/moral-hypocrisy

Nordquist, Richard. "The Character of the Man in Black' by Oliver Goldmith." Thought Co, 2019.

"Oliver Goldsmith." Britannica, https://www. britannica.com/biography/Oliver-GoldsmithAnglo-Irish-author

"Oliver Goldsmith." Editor Eric's The Greatest Literature of All Time, http://www.editoreric. com/greatlit/authors/Goldsmith.html
"Oliver Goldsmith Short Fiction Analysis." ENotes, 2018.

Sie, Maureen. "Moral Hypocrisy and Acting for Reasons: How Moralizing can Invite SelfDeception." Ethical Theory and Moral Practice, vol. 18, 2015, pp. 223-235.

"Social Learning Theory (Bandura)." Learning Theories, https://www.learning-theories.com/ social-learning-theory-bandura.html

Taylor, Richard C. Goldsmith as Journalist. Associated University Presses, 1993

"The Man in Black." Full Online Books, http://m. fullonlinebook.com/essays/the-man-in-black/ gzky.html

\section{Author Details \\ Dr. Mary Raymer, Assistant Professor, St. Aloysius' College, Jabalpur, Madhya Pradesh, India, \\ EmailID:marymrons@gmail.com}

Ms. Neha Mahawar, St. Aloysius' College, Jabalpur, Madhya Pradesh, India 